\title{
Effect of Milking Procedure and Handling on its Quality
}

\author{
Gelane Kumssa* \\ Ethiopia Institute of Agricultural Research, Debre Zeit Agricultural Research Center, Ethiopia
}

Submission: September 12, 2018; Published: October 11, 2018

*Corresponding author: Gelane Kumssa, Ethiopia Institute of Agricultural Research, Debre Zeit Agricultural Research Center, Ethiopia, Tel: 920117063; Email: k.gelane@gmail.com

\begin{abstract}
The study was conducted at Haramaya University to evaluate the effect of Milking Procedure and Handling on Quality of Milk. The study was carried out to assess the milking procedure, handling and quality at farm. The previous status of the farm and important information was acquired from farm manager in the form of interview. Milking procedure of all milking cows observed reputedly for six days at the farm and all procedures followed are recorded. Ease of cleaning, equipment's, cooling facility and transportation was observed. Laboratory analysis was carried out to determine the Microbial quality, chemical composition, clot on boiling and Alcohol test of raw milk. From the farm observation poor milking, milkiers, milk transportation methods were observed. The collected fresh milk sample checked with alcohol and clot on boiling testes was positive. The specific gravity of the sample was 1.028. The pH and milk acidity of fresh milk were 7 and 0.198 percent respectively. The contents of fat, protein and total Solid contents of raw fresh milk were 3.7, 3.3 and 12.36, respectively. The overall mean total bacterial count of raw milk produced in the farm was $6.65 \mathrm{log} \mathrm{cfu} / \mathrm{ml}$. This value is higher than the acceptable value of $1 \mathrm{x} 105$ bacteria per ml of raw milk. In general, the result indicated that milk samples collected from the farm were subjected to microbial contamination and does not meet the international quality standard. Therefore, adequate sanitary measures should be taken at a farm.
\end{abstract}

Keywords: Milk; Hygienic practices and Milk quality

\section{Introduction}

Ethiopia currently manages the largest livestock population in Africa for different purposes, such as milk production, meat production, traction, transportation, egg production, biogas, fuel, traditional fertilizer and different medicinal values. Milk production is the important dairy productivity serves as nourishment for new born calves and food for infants and for adult humans [1]. Approximately 3.2 billion liters of milk produced from 10 million milking cows at an average of 1.54 litters milk per cow per day over lactation period of 180 days. The estimated calf consumption and wastage of milk is $32 \%$ of the milk produced [2]. Milk wastage or post-harvest losses are high in dairy farm of Ethiopia. This occur due to poor milking procedure, handling during milking, utilization, storage (lack of cooling facilities), transportation (delay time transportation). All these factors results rejection of milk from the market in case of adulteration foreign material (liquid and solid material) and increase microbial load in the milk [3].

On one hand rapidly growing the human population with growing rate of urbanization is resulting in a shift in demand for dairy products. Levels of malnutrition are consequently high. The FAO estimates that about 51 percent of the population is undernourished and over two million people are chronically food insecure [1]. Compared to other countries in Africa, Ethiopians consume fewer dairy products. Per capita consumption of milk in Ethiopia is as low as $17 \mathrm{~kg}$ per head while the average figure for
Africa and world is37.2and 6okg per man respectively [4]. This may the result of low milk production and post-harvest losses due to contamination with dirty material which followed by microbial deterioration.

The common predisposing factors of milk contamination by microorganisms are milking environment, cows and milking personnel, milking equipment, and water [3]. All these factors make appropriate condition for the multiplication microorganisms particularly bacteria in milk, and hygienic production is very important for high quality milk production. Dirty milking places and handling equipment tend to breed flies which may fall in milk causing contamination and thus spoilage may occur [3]. Therefore, maintaining the sanitary condition of the milking area is milking equipment personal hygiene important to produce good quality milk [5].

Therefore, standard milking procedure and hygienic handling is the ideal and conscientious to be considered, and thus, minimize milk wastage, prevalence of mastitis and increase the value of produced milk. Therefore, understanding of milking procedure and handling of milk are paramount importance to make future improvement interventions; and were poorly considered in the study farm. Therefore, the general objective of this paper is to assess milking procedure, handling and microbial properties of milk at Haramaya University dairy farm. 


\section{Material and Method}

\section{Area Description}

The experiment was conducted at dairy farm of Haramaya University, located $505 \mathrm{~km}$ east of Addis Ababa. The site is situated at an altitude of 1980 m.a.s.l, 9026 ' $\mathrm{N}$ latitude and 4203 ' E longitude. The area has an average annual rainfall of $741.6 \mathrm{~mm}$, the mean annual minimum and maximum temperatures are $8.25^{\circ} \mathrm{C}$ to $23.4^{\circ} \mathrm{C}$, respectively.

\section{Haramaya University Farm Status and Animal Manage- ment}

Haramaya University is one of the typical higher learning institutes in Ethiopia, and dairy farm established for teaching and practical session for students, research work and community service in the area. Now a day cross breed has kept which has two exotic bloods (Jersey and Holstein Friesian) and one local blood (Horror) but, their blood level was not known (Ewuonetu Kebede, personal communication). Currently the herd composition was milking cows with different lactation stage, pregnant cows, heifers, calves, breeding bull, weaned male calves and dry cows in the farm. Herd management include all the managemental aspects in the farm include housing, feeding, providing water, cleaning farm and other related managements. Feeding management of Haramaya University farm carried out by segregating animals according to their age and sexes. New born calf fed colostrum for seven days by suckling their mother and the remaining colostrum in the udder milked by hand and provided for calf in bucket as adlibitum for seven days. After that the calf detaches her mother and starts bucket feeding, and after 15 days started to exercise roughage feeding, and kept separately with their matches up to three months.

From age of three to six months calves were managed separately in more similar condition of milk in bucket feeding and roughage feed. Concentrate provide depend on the body condition of the calves (if emaciated only). Similarly, the other livestock (pregnant cows, bull, heifers, dry cows, male calves and lactating cows) also managed separately with three types of feeds (concentrate, roughage and sometimes green feed) and all feed provided were not weighted due to absence of weigh balance in the farm, provided only by estimating its weight. Pregnant cows after they reach seven months separated from the herd and supplemented with concentrate feed for steaming up purpose. All animals have free access to water. The water barn cleaned per week and new water changed. Whole farm cleaned per day and the dung taken away by tractor for different need such as compost and biogas. Breeding system of the farm was the bull service. The distance of the area from the capital city of the country enforces to need this method, which was difficult to bring the semen to the farm for artificial insemination.

\section{Sampling Procedure}

The study was carried out to assess the milking procedure, handling and quality at Haramaya university farm. The previous status of the farm and important information was acquired from farm manager, (Euonetu Kebede) in the form of interview. Milking procedure of all milking cows observed reputedly for six days at the farm and all procedures followed are recorded. Ease of cleaning milk handling equipment's, cooling facility and transportation is observed. Milk sample was taken to Haramaya University milk and nutrition lab for quality analysis.

\section{Milk Quality Tests}

To evaluate the quality of milk destined, preliminary quality tests were taken. These were: alcohol, Clot-on-boiling and specific gravity.

Alcohol Test: The alcohol test is a simple test used for fresh milk to indicate whether it will coagulate on processing (heat treatment). Milk that contains more than $0.21 \%$ acid will coagulate when alcohol is added. Alcohol test will be performed by putting equal volumes of milk and $68 \%$ of ethyl alcohol in a test tube. The test tube was inverted several times with the thumb held tightly over the open end of the tube. The tube was then examined to determine whether the milk has coagulated or not. If it has fine particles of curd will be visible.

Clot-On-Boiling Test: The clot-on-boiling test is used to determine whether milk is suitable for processing, as it indicates whether milk is likely to coagulate during processing (usually pasteurization). The test measures the same characteristics as the alcohol test but is somewhat more lenient ( 0.22 to $0.24 \%$ acidity, as compared to $0.21 \%$ for the alcohol test). It has the advantage that no chemicals are needed. Clot-on-boiling test was carried out by placing about five $\mathrm{ml}$ of milk in a test tube and then it was placed in a boiling water bath for five minutes. Finally; the test tube was carefully removed from the water bath and shake carefully and lastly, examined for the presence of floccules.

Specific Gravity Test: Specific gravity is the relation between the mass of a given volume of any substance and that of an equal volume of water at the same temperature. Since the mass of a given volume of water at a given temperature is known, the volume of a given mass or the mass of a given volume of milk can be calculated from its specific gravity. For example, one liter of water at $4^{\circ} \mathrm{C}$ has a mass of $1 \mathrm{~kg}$, and since the average specific gravity of milk is 1.032 , one liter of average milk will have a mass of $1.032 \mathrm{~kg}$.

The material used in this method is lactometer, biker and milk sample. Milk density was determined by using lactometer. A milk sample taken, and the milk mixed thoroughly and gently to avoid incorporation of air bubbles. The lactometer read was taken after it inserted into the milk and lifted to float freely until it rested. Milk temperature reading is recorded immediately. The milk density was calculated based on the results of the lactometer reading and milk temperature according to the formula described by O'Connor.

$$
\text { Specific Gravity }=\frac{((L))}{1000}+1
$$

Where,

L - Corrected lactometer reading at a given temperature. 
pH

$\mathrm{PH}$ is used to measure acidity of the milk whether is acidic, neutral and alkaline. PH less than 7 indicates acidity, greater than 7 is alkalinity and pH equal to 7 is neutral. PH measurement materials are $\mathrm{pH}$ meter and two standard buffers which are made from palinated tablet to adjust the $\mathrm{pH}$ meter. These standard buffers have $\mathrm{pH} 4$ and $\mathrm{PH} 7$ and used to standardize $\mathrm{pH}$ meter. After the $\mathrm{pH}$ meter standardized both $\mathrm{pH}$ and temperature measurement inserted to the milk sample and $\mathrm{pH}$ value of the milk observed on $\mathrm{pH}$ meter.

\section{Milk Acidity}

Acidity measurement is will be carried out by titration of milk sample with $\mathrm{NaOH}$. The important chemicals are $\mathrm{NaOH}$ and phenol, the important equipment is burette and biker. $0.1 \mathrm{ml} \mathrm{NaOH}$ added into the burette. $10 \mathrm{ml}$ of milk sample poured into biker. 5 drop of phenol added into milk sample in the biker. Then $\mathrm{NaOH}$ drops added to milk sample from the burette and stirred up to the color of the sample changed to pink. The acidity of sample calculated as

$$
\frac{\text { Amount } \mathrm{NaOH} \text { needed } * 0.009}{\text { amount of milk sample }} * 100
$$

\section{Determination of Major Chemical Composition of Milk}

The major chemical composition of milk includes: percent of total solids, fat, and protein. Milk fat analysis was done by Gerber method. The materials needed in milk fat content determination were sulfuric acid 68\%, amyl alcohol, centrifuge, distilled water. First $11 \mathrm{ml}$ of milk sample, $10 \mathrm{ml}$ of sulfuric acid, and $1 \mathrm{ml}$ of amyl alcohol were measured and added in to the tube. Then little amount of water added and stoppered properly. Then mixed thoroughly and putted in water bath at $63 \%$ for five minutes. Next, removed from the water bath carefully and centrifuged for five minutes and returned to water bath for five minutes. Finally, floated and concentrated fat together from the tube reading was recorded.

Protein content will be determined by using the formaldehyde titration method. The important chemicals in the protein content determination were potassium oxalate, phenol, sodium hydrooxide, and formalin aldehyde. First $10 \mathrm{ml}$ of milk sample, 0.5 of potassium oxalate and $0.4 \mathrm{ml}$ of phenol added carefully into biker. Then sodium hydro-oxide poured in to the burette and its drop needed and stirred up to the color changed to pink. After that twopipetting drop of formalin aldehyde added into the sample and the pink color will changed. The again sodium hydro-oxide drop needed and stirred up-to the color of the sample return to pink. Lastly calculating the protein percent using sodium hydro-oxide used after drop of formalin aldehyde.

\section{Calculation $\mathrm{ml}$ of $\mathrm{NaOH} \times 1.4=\%$ of protein}

Total solids (TS) was determined by oven drying $5 \mathrm{~g}$ of milk sample dry in the drying oven at $100^{\circ} \mathrm{C}$ for 4 hours.

\section{Calculation}

$$
\text { Total solid Content }=\frac{M 2-M 0}{M 1-M 2} * 100
$$

\section{Where:}

$\mathrm{M} 0=$ the mass, in grams, of the dish and lid

M1 = the mass, in grams, of the dish, lid and test portion

M2 = the mass, in grams, of the dish, lid and dried test portion

\section{Total Bacteria Count}

The material used in the experiment were test tube, pipet tube, measuring cylinder, aluminum foliage, feuwmuud, pan, flame, milk sample, volta, pencil, note book, alcohol, petridish, thermometer, and chemicals were peptone water, plate count agar and violate red agar. All equipment's that have contact with the sample were washed and sterilized in autoclave at $121{ }^{\circ} \mathrm{C}$ for 15 minutes to avoid any contamination with microorganism. The chemicals needed also sterilized except violate red agar. The equipments and chemicals placed on the feuwmuud and $9 \mathrm{ml}$ of peptone water added into 6 test tubes and $1 \mathrm{ml}$ of milk sample added into the first $10 \mathrm{n}-1$ test tube and diluted using volta. Fleming was used in every and each activities of sample poured and transferred. Then $1 \mathrm{ml}$ of the diluted in $10 \mathrm{n}-1$ transferred to the second test tube or $10 \mathrm{n}-2$ and again diluted. Next $1 \mathrm{ml}$ of diluted $10 \mathrm{n}$-2transferred to the $10 \mathrm{n}-3$ test tube and continued up to the six or end of prepared test tube.

All diluted samples are stoppered with aluminum foliage. Then the $1 \mathrm{ml}$ of sample taken from each of the test tube and placed on every individual petri dishes (each sample was placed on two individual petri dishes for plate count agar and violate red bile agar) and solidified for 15 minutes. After that $1 \mathrm{ml}$ of palate count agar added on one of the solidified samples on petri dish drawn from each test tube and $1 \mathrm{ml}$ of violate red bile agar on another solidified petri dish. The sample solidified with palate count agar was to count gram positive bacteria and sample solidified with violate red agar was to count gram negative bacteria. Both were solidified again, and palate count agar incubated for 48 hours and violate red bile agar incubated for 24 hours at $37^{\circ} \mathrm{C}$. Finally, the counts were made using colony counter. The plate counts will be calculated by multiplying the count on the dish by 10 n, in which n stands for the number of consecutive dilutions of the original sample (Marth, 1978).

\section{Data Organization and Analysis}

The collected through interview, observation and lab test was organized and processed using simple statistical method.

\section{Result and Discussion}

\section{Hygienic Milking Practices and Procedure}

Environmental hygiene is one of the key basics to produce clean and healthy milk. At Haramaya University farm the barn cleaned only once a day in all season in the year and milking parlor cleaned twice a day after milking morning and afternoon. Clean water also available all the time in the parlor. The parlor was well-constructed concrete floor have two doors for entrance and exit of lactating cows excluding the other doors. Five milking machines were organized for milking and cows lactating in order. 
The trough to provide feed during milking were present, but feed were not provided during milking, because can it contaminate the milk during milking. Water heating facility (stuff) also available for water heating which used to clean milk handling equipment.

Arrangement of cows for milking according to their milk yield, udder with mastitis problem and other criteria was not seen at the farm. All lactating animals have equal right to be milked first at the farm. In standard milking procedure, high yielder lactating cow, low yielder, cows with clinical mastitis and pregnant heifers to milked first, second, third and fourth respectively. Pregnant heifers were for only exercise milking for future lactation.

Dairy cows are creatures of habit. Therefore, the management program must always include consistent milking times each day and the same basic milking procedure for all cows. Despite this the handling of cow somewhat poor which the body and udder of the cow (except teats) were dirty during milking. This can easily contaminate the milk. Similarly, the research carried out at Combolcha woreda at smallholder level stated that, most of the farmers in the woreda were not wash udder before milking, even if they believe as the calves during suckling before milking clean the teats [6]. Personal hygiene has seen on milkers, where they cover their hair; wear overall clothes, eye glasses and gumboots. All milkier in the farm were uneducated and the university management offers them with training on milking procedure and hygiene. Providing feed during milking was not seen. Because the feed contaminates the milk and the cows become disturbed after they finish the feed; and try to eat the other cows feed which are milking in parallel.
Important functions of fore-stripping is to check for abnormal milk (such as clots, watery secretions) as an early detection of clinical mastitis, ensures that the teat canal is open for free flow of milk, stimulates the release of oxytocin to enhance milk let down. Unfortunately, fore-stripping was not practiced in the parlor. This increase the transmission of zoonosis disease from animal to human through milk ingestion. Little attention taken to udder swelling to identify its abnormality. FSA reported that cleaning of the udder before milking is important to remove both visible dirt and bacteria from the outer surface of the udder. Unless properly handled, milk can be contaminated by microorganisms at any point from production to consumption. Producers should therefore make udder washing a regular practice to minimize contamination and produce good quality milk. Production of milk of good hygienic quality for consumers requires good hygienic practices (clean milking utensils, clean milkier's, washing the udder and use of individual towels) during milking and handling, before delivery to consumers or processors.

Teats were cleaned with cold water and towel and dried before milking. Individual towel not needed for clean and dry whereas all cows needed only one towel for cleaning and one towel for drying off. This can transmit disease between milking animals. This result is comparable with the finding of Haile [7] carried out at Hawassa stated that, most of the milk producers (48\%) in the area do not use towel to dry udder after washing rather they massage the udder with bare hands; while about $44 \%$ of them reported to use common towel while $4.6 \%$ reported that they do not practice udder washing and drying. The proportion of producers that reported to use separate towel for each cow accounted to only $3.8 \%$.

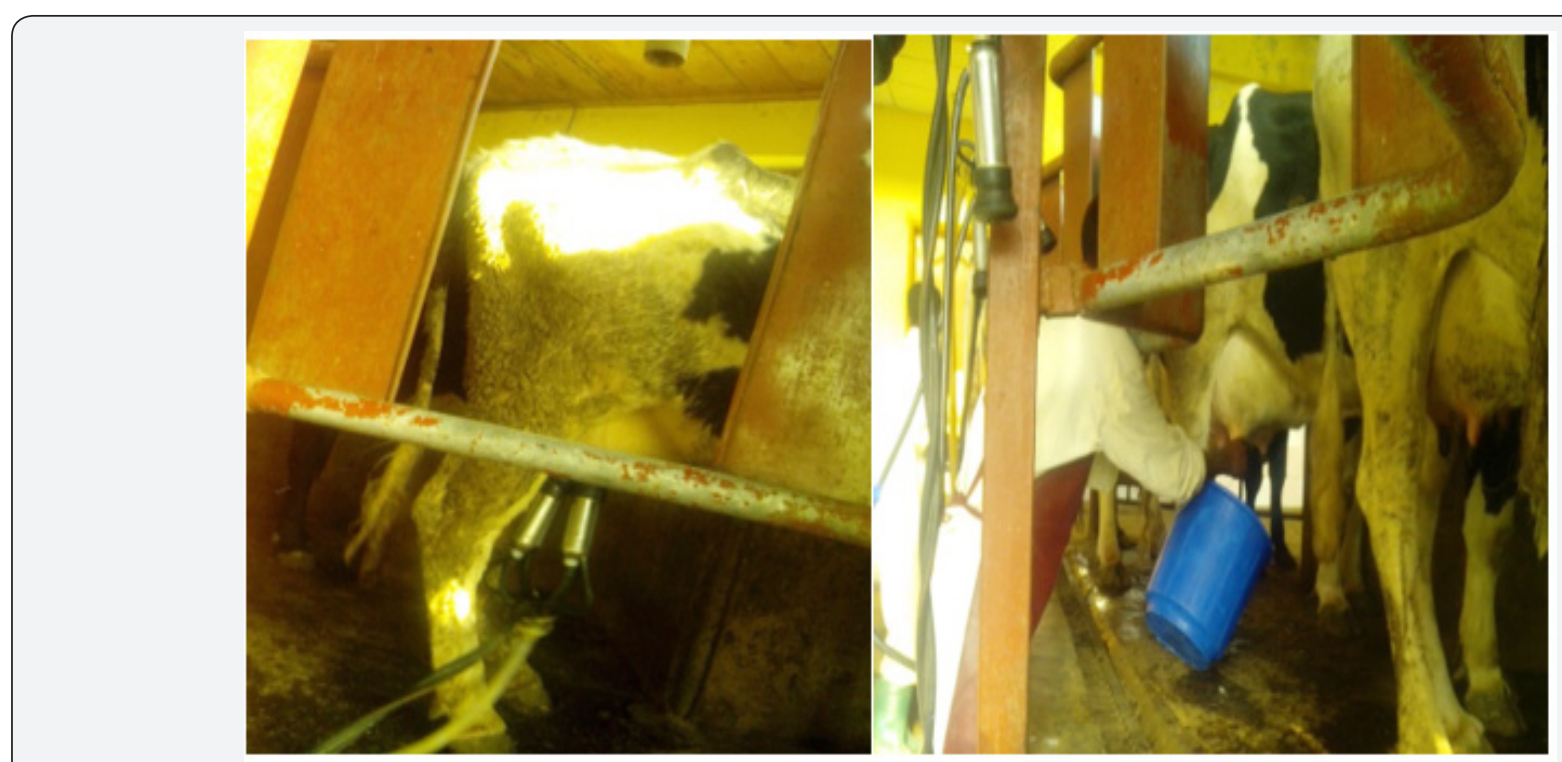

Figure 1: Cow hygiene and Hand milking of abnormal or unfitted teats to milking machine.

Pre-dipping was not practiced, and the milking unit attached after the teats dried off. Milking time was 4 to 10 minutes up to the last milk squired out. Sometimes the milkier not consider all cows equally and over milking also seen. The udder or teats which have injury or abnormality or unfit to machine was milked by hand. Detachment of the milking unit was done by gradual pushing of the unit before shutting off the machine vacuum. In standard milking procedure milking unit should be removed after the machine vacuum has shuttled off (Figure 1). After the milking machine has detached disinfectant was painted the teats by towel. But, in standard milking procedure, teats should dip with individual dipping cup and the method use was different from 
standard milking procedure. Finally, the cow exited the parlor and provided with concentrate feed after milking, and never lying down up to the teats dried very well.

Milking units were washed by hot water and detergents thoroughly after all cows milked. The harvested milk was weighted for each cow separately and the yield obtained from was recorded. All milks filtered and poured into the Jerica or others milk transporting equipment's and transported to milk shopping or distributing center in the university (Figure 2). The materials used during milking were made up of aluminum which has no toxicity, but transporting materials were plastic materials. Milk cooling is not practiced in the farm where all milk purchased immediately after milking. Similarly, fumigation of the milking and transporting equipment's was not practiced, where all equipment's washed with hot water and detergents.
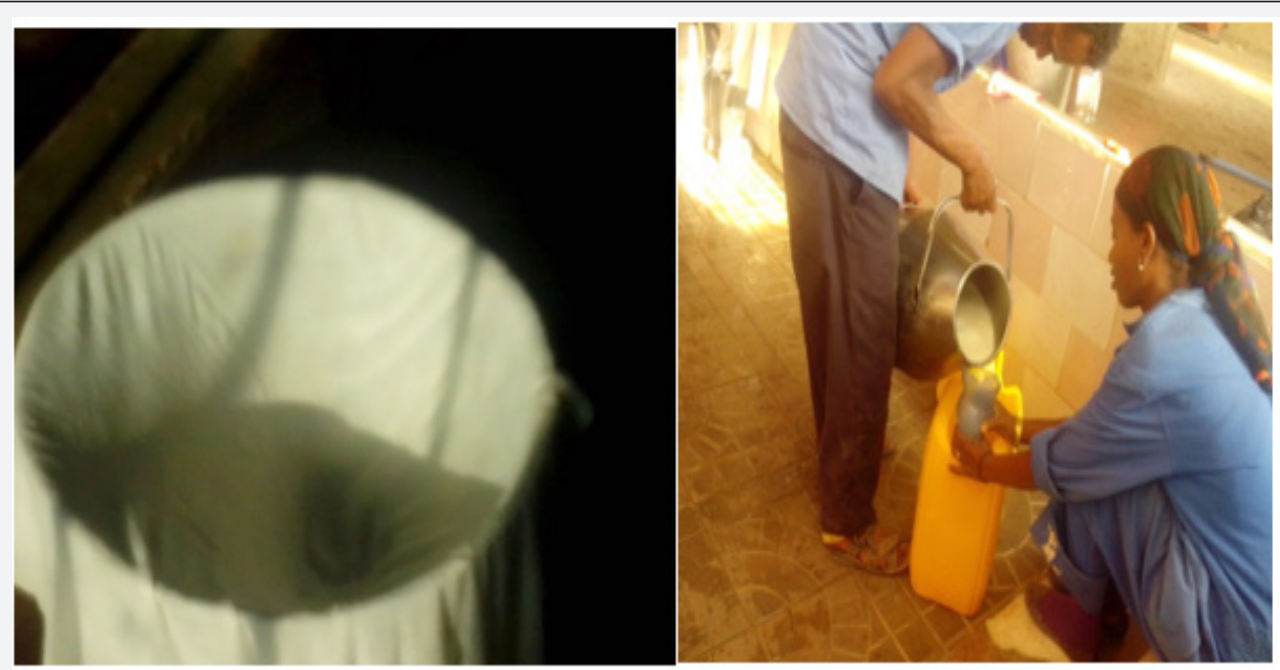

Figure 2: How to Filter and Transport to Milk Distributing Center.

\section{Alcohols Test, Clot on Boiling Tests and Specific Gravity}

The collected fresh milk sample checked with alcohol and clot on boiling testes was positive. The specific gravity of the sample was 1.028. Similarly, several reports have reported on specific gravity of milk such as Alehegne [8] reported specific gravity ranging from 1.025 to 1.029 for Small holder dairy farms in Debre Zeit. Zelalem reported that majority raw whole milk sample collected from Holetta and Selale area their specific gravity was fall within the range between 1.028 and 1.032. The normal specific gravity of milk ranges of 1.026 to 1.032 [9].

\section{pH and Acidity}

Fresh milk has $\mathrm{pH}$ ranges between 6.5-6.9 and acidity ranges between 0.22 to 0.24 percent. As the milk settled for long time the $\mathrm{pH}$ become decrease and acidity increase. The $\mathrm{pH}$ and milk acidity of fresh milk of the Haramaya University dairy farm were 7 and 0.198 percent respectively. The pH more than or less than the normal range indicate presence of mastitis and acidity respectively. The acidity more than the normal range indicates the presence of bacteria in the milk [9].

\section{Chemical Composition}

Table 1: Milk constituent at Haramaya University farm.

\begin{tabular}{|c|c|}
\hline Milk Chemical Composition & Percent \\
\hline Fat & 3.7 \\
\hline Protein & 3.3 \\
\hline Total solid & 12.36 \\
\hline
\end{tabular}

The contents of fat, protein and total Solid contents of raw fresh milk were 3.7, 3.3 and 12.36, respectively. The result obtained was showed in the Table 1 below:

The fat content of raw whole milk observed in the current study is much less than values reported earlier. Alganesh [10] indicated the value to $6.1 \%$ for Horro breed in Eastern Wollega. This might be due to the variation in milk fat content among genetically different breeds of cows and for the different stages of lactation. The protein content of milk as observed in the current study was 3.3 percent. The values obtained in the present study are consistent with that by Alganesh [10] 3.31\% protein content for milk samples collected from smallholder producers in East Wollega. The total solid obtained was $12.36 \%$, and lower than the result reported by Helen, (2007) in Combolcha woreda, where was $16.67 \%$.

\section{Total Bacteria Count}

The overall mean total bacterial count of raw milk produced in the farm was $6.65 \mathrm{log} \mathrm{cfu} / \mathrm{ml}$. This value is higher than the acceptable value of $1 \times 105$ bacteria per ml of raw milk. This high level of contamination of milk might be due to initial contamination originating from the udder surface, quality of cleaning water, milking utensils. Therefore, total bacterial count is a good indicator for monitoring the sanitary conditions practiced during production and handling of raw milk $[11,12]$.

\section{Conclusion and Recommendation}

Milk is very important nourishment for human and new born calves whereas its demand is high in the country. Milk production 
is mainly depending on the indigenous livestock whereas processing and marketing depend on the production system in the country. In urban and peri-urban area fresh raw milk mostly sold, whereas the milk produced far away from the milk shed was processed. Low production and postharvest losses make unable to satisfy the growing human population in Ethiopia. Postharvest loss is high due to poor hygiene of milk handling equipment, milking procedure, cow, environment, milkier, storage equipment and others that have contact with cow or milk.

Following the standard milking procedure increase the qualities of milk. In contaminated milk the microorganisms multiply rapidly and the product become unfit for consumption. This increases the percent of postharvest losses and reduces the income. Therefore, following proper milking procedure and make the environment, milkier, milk handling equipment, cow and all others have contact with milk clean is the improvement of hygiene and raise of income from milk and milk products.

\section{References}

1. Hemme T, Otte J (2001) FAO (Food and Agriculture Organization) Status and prospects for smallholder milk production: A global perspective, Rome, Italy.

2. MoARD (Minister of Agricultural Rural Development) (2005) Agricultural marketing strategy, Addis Ababa, Ethiopia.

3. Mbabazi P (2005) Milk industry in Uganda, (1 $1^{\text {st }}$ edn), Fountain Publishers Kampala, Uganda p. 27-52.

4. Jurjen Draaijer (2007) FAO (Food and Agricultural Organization) Milk producer group resource book: a practical guide to assist milk producergroups, Rome, Italy.
5. Zelalem Yilma (2010) Quality factors that affect Ethiopian milk business: Experiences from selected dairy potential areas. Netherlands Development Organization, Addis Ababa, Ethiopia.

6. Helen Nigussie (2007) Traditional handling practices, preservation methods and evaluation af the lactoperoxidase system and container smoking on microbial quality of cows'and goats' milk in Combolchaworeda, Eastern Ethiopia. MSc. Thesis presented to the school of graduate study of Haramaya University, Ethiopia.

7. Haile Welearegay, Zelalem Yilma, Yosef Tekle (2012) Hygienic practices and microbiological quality of raw milk Produced under different farm size in Hawassa, Southern Ethiopia. Agric Res and Rev 1(4): 132- 142.

8. Alehegne, Wubet (2004) Bacteriological quality of Bovine milk in small holder dairy farms in Debrezeit, Ethiopia M.Sc Thesis Addis Ababa University, Ethiopia.

9. Kurwijila LR (2006) Hygienic milk handling, processing and marketing: reference guide for training and certification of small-scale milk traders in Eastern Africa. ILRI (International Livestock Research Institute), Nairobi, Kenya.

10. Alganesh Tola (2002) Traditional milk and milk products handling practices and raw milk quality in Eastern Wollega. M.Sc. Thesis, Alemaya University. Dire Dawa, Ethiopia.

11. Chambers JV (2002) The microbiology of raw milk. Dairy Microbiology Handbook. pp. 39-90. In: Richard, K. ( ${ }^{\text {rd }}$ ed.), Robinson. John Wiley and Sons, New York, USA.

12. Mc Donald P, Edwards RA, Greenhalgh JFD, Morgan CA (1995) Animal Nutrition. $\left(5^{\text {th }}\right.$ edn), Longman Scientific and Technical. Copublished in the United States with John wiley and Sons, Inc., New York, USA, pp. 607.

\section{Your next submission with Juniper Publishers} will reach you the below assets

- Quality Editorial service

- Swift Peer Review

- Reprints availability

- E-prints Service

- Manuscript Podcast for convenient understanding

- Global attainment for your research

- Manuscript accessibility in different formats ( Pdf, E-pub, Full Text, Audio)

- Unceasing customer service

Track the below URL for one-step submission https://juniperpublishers.com/online-submission.php 